\title{
Comparison of Culture of Goat Milk with Indirect Measurement of Somatic Cell Count Using a Commercial Kit, and Antimicrobial Susceptibility of Bacterial Isolates
}

\author{
Ross Peterson ${ }^{1}$, Harry Hariharan ${ }^{1}$, Vanessa Matthew ${ }^{1}$, Graeme Stratton ${ }^{2}$, \\ Cecilia Hegamin-Younger ${ }^{3}$ and Ravindra Sharma ${ }^{1}$ \\ ${ }^{1}$ Pathobiology Academic Program, School of Veterinary Medicine, St. George's University, Grenada, \\ West Indies \\ ${ }^{2}$ Large Animal Medicine and Surgery Academic Program, School of Veterinary Medicine, St. George's \\ University, Grenada, West Indies \\ ${ }^{3}$ Department of Public Health and Preventive Medicine, School of Medicine, St. George's University, \\ Grenada, West Indies
}

Correspondence should be addressed to: Harry Hariharan; hhariharan@sgu.edu

Received Date: 5 December 2013; Accepted Date: 17 February 2014; Published Date: 21 May 2014

Academic Editor: Savas Atasever

Copyright (C 2014 Ross Peterson, Harry Hariharan, Vanessa Matthew, Graeme Stratton, Cecilia Hegamin-Younger and Ravindra Sharma. Distributed under Creative Commons CC-BY 3.0

\begin{abstract}
Detection of sub-clinical mastitis in goats is important in the prevention of clinical mastitis, and for the development of treatment protocols. The PortaSCC goat milk test ${ }^{\circledR}$ (Porta-test) is a novel commercial test for indirect somatic cell count (SCC), and is marketed as a rapid diagnostic method to monitor udder health. The purpose of this study was to compare the results of the Porta-test with culture results, identify bacterial intramammary pathogens in the goats of Grenada, and determine their antibiotic sensitivity. Udder half milk samples from 150 goats in various stages of lactation were evaluated from separate herds on the island state of Grenada. Of 74 udder halves, randomly chosen and studied using the Porta-test, 23 (31\%) had normal SCC (category 1), and 51 $(69 \%)$ had higher SCC, falling in 3 categories of Porta-test positive samples, with $35.2 \%$ positives on culture. The differences in culture positivity in the 4 Porta-test SCC categories were statistically not significant. Although indicative of inflammation, the use of this rapid diagnostic method cannot be solely relied upon for the determination of subclinical mastitis of bacterial origin in the caprine. Of the 24 bacterial isolates, $42 \%$ were Staphylococcus simulans, and the remaining isolates included one isolate, each of several coagulase-negative species of staphylococci. Of the 24 isolates tested for susceptibility against 12 antimicrobial drugs, only 2 showed resistance, one for penicillin and erythromycin, and one for tetracycline.
\end{abstract}

Keywords: Goat milk, somatic cell count, diagnostic kit, bacteria, drug susceptibility.

Cite this Article as: Ross Peterson, Harry Hariharan, Vanessa Matthew, Graeme Stratton, Cecilia HegaminYounger and Ravindra Sharma (2014), "Comparison of Culture of Goat Milk with Indirect Measurement of Somatic Cell Count Using a Commercial Kit, and Antimicrobial Susceptibility of Bacterial Isolates," International Journal of Veterinary Medicine: Research \& Reports Vol. 2014 (2014), Article ID 710797, DOI: $10.5171 / 2014.710797$ 


\section{Introduction}

Mastitis is one of the most serious economic and health problems of dairy goats worldwide. The inflammation of the mammary gland can cause gross variations in milk composition, reflected by physical, chemical, and bacteriological changes. There may be a decrease of important components like lactose, casein, fats, and minerals such as calcium, phosphorous, and potassium, and increases in other unimportant components such as serum proteins and chlorides (Oliszewski et al., 2004). While the clinical form is characterized by symptoms, including abnormalities in milk, the subclinical form is subtle, and the milk often appears to be normal. The subclinical form constitutes a reservoir of microorganisms that can prompt infection of other animals within the herd, and may precede the clinical form. According to Philpot (1984), it is utterly futile to think that mastitis can be controlled by the treatment of clinical mastitis. Somatic cell count (SCC) is the indicator most commonly used for mastitis detection in the bovine. The SCC values, and the type of bacteria involved in clinical and subclinical mastitis in goats, can vary considerably between different countries and between regions in the same country. The relative and absolute importance of different pathogens may also vary from one geographic area to another. It is important to generate baseline information for accurate diagnosis and preventive/control measures. While determination of actual SCC values for goats requires a direct microscopic method using the DNA-specific stain pyronin Y-methyl green (Petersson et al., 2011); commercial kits such as "PortaCheck" have recently appeared on the market. "PortaSCC $®$ goat milk test" (Porta-test) is based on a chemical reaction between a dye on the test strip and an enzyme found on the surface of somatic cells in the milk. This test comes with claims to detect a lower level of somatic cells than the standard California Mastitis Test (CMT), which uses a concentrate that will gel in relation to somatic cell count and was developed to determine bovine mastitis.
Therefore, the Porta-test should have a greater sensitivity for identifying subclinical mastitis in the caprine. The sensitivity and specificity of the Porta-test for the bovine is reported to be $76 \%$ and $94 \%$, respectively when compared against the Bently 300 Somatacount machine as the gold standard (Leslie et al., 2006). The California Mastitis Test is reported to have a range of sensitivity and specificity from $73-89 \%$ and $75-85 \%$ respectively, however the gold standard used to confirm these findings is bacterial culture (Ruegg and Rienemann, 2002). It has been noted that factors such as caprine arthritisencephalitis virus infection and stress can contribute to an increase in SCC in the caprine, making the sole use of SCC for predicting mammary infection in the goat difficult (Lerondelle et al., 1992). Many farms currently rely on the Porta-test to monitor udder health. It is more costly than the California Mastitis Test; however, a more accurate interpretation of on-farm somatic cell counts can be a useful screening tool. This study was primarily intended as a comparative study of culture results with Porta-test results, considering the fact that there has been no published report on such comparison. The study also determined the types and numbers of potential intramammary bacterial pathogens from lactating goats in Grenada, and their antimicrobial susceptibility.

\section{Materials and Methods}

All goats selected for this study were from the island of Grenada, and were assigned a number and identified with regard to age, stage of lactation if known, herd location and any illness or treatment history. The animals in this study were not kept in a traditional farm setting, and were kept in very rugged terrain, which is typical of this island. A total of 150 animals, representing all known lactating animals that met the selection criteria on the entire island during the time of study, were included. Any does with signs of clinical mastitis, visible signs of damage to the udder, or showing outward signs of illness were excluded from the study. To 
determine subjects and udder half, the simple random sample method was used. Seventy four udder halves were randomly chosen for the study. Individual udder half samples were identified as Right (R) or Left (L), and samples were collected as outlined by Quinn et al., (1994). The teat was thoroughly wiped with $70 \%$ ethyl alcohol, paying particular attention to the teat orifice. One minute was allowed to elapse before sample collection. A small amount of milk was first stripped from the udder, and then a capped sterile wide mouth tube was used to collect the sample. The samples were then labeled and stored at $4^{\circ} \mathrm{C}$ for not more than 2 hrs before testing and culture.

Indirect somatic cell count tests were performed in the laboratory on samples brought to room temperature, using the Porta-test protocol outlined by the manufacturer. For Porta-test, SCC (cells $/ \mathrm{ml}$ ) of $<500,000$ is interpreted as normal, $500,000-1,000,000$ as weak udder infection, $1,000,000-1,500,000$ as indicative of possible udder health problems, and over 1,500,000 as indicative of udder infection.
For culture, a $0.01 \mathrm{ml}$ sample of milk was plated on Columbia blood agar and MacConkey agar using a calibrated loop. The plates were incubated at $37^{\circ} \mathrm{C}$ for up to 72 hours, examined for the number and type of colonies and the information recorded. A plate was considered positive if there was greater than one colony cultured. The bacteria were identified based on colony morphology, hemolytic patterns, Gram's stain; and tests as required for catalase, coagulase, oxidase, and finally using API bacterial identification strips ("ID32 STAPH", rapid ID32 STREP, api Coryne, api 20E, and api 20NE; bioMerieux) (Hariharan et al 2004). Additional tests including esculin hydrolysis using Edward's agar, and CAMP tests (Quinn et al., 1994) were utilized for certain isolates.

The number of samples positive on culture from each of the 4 Porta-test SCC categories (Table 1) were compared for statistically significant differences using the chi-square test.

Table 1. Porta-Test SCC Results and Bacterial Isolation

\begin{tabular}{|c|c|c|c|}
\hline $\begin{array}{l}\text { SCC as per Porta- } \\
\text { test }\end{array}$ & $\begin{array}{l}\text { No. of samples with } \\
\text { corresponding SCC }\end{array}$ & $\begin{array}{l}\text { No. of samples } \\
\text { positive ( }>1 \text { colony) } \\
\text { on culture }\end{array}$ & Bacterial isolates and number positive \\
\hline $\begin{array}{l}\leq 500,000 \\
\text { (Normal) }\end{array}$ & 23 & $4 / 23(17.4 \%)(\mathrm{A})$ & $\begin{array}{l}\text { Staphylococcus lugdunensis (1) } \\
\text { Staphylococcus simulans (1) } \\
\text { Staphylococcus caprae (1) } \\
\text { Staphylococcus sciuri (1) }\end{array}$ \\
\hline $\begin{array}{l}500,000- \\
1,000,000 \\
\text { (Possible weak } \\
\text { udder infection) } \\
\end{array}$ & 24 & $8 / 24(33.3 \%)(B)$ & $\begin{array}{l}\text { Staphylococcus simulans (4) } \\
\text { Staphylococcus capitis (1) } \\
\text { Corynebacterium spp. (1) } \\
\text { Streptococcus spp. (1) } \\
\text { Micrococcus spp. (1) }\end{array}$ \\
\hline $\begin{array}{l}1,000,000- \\
1,500,000 \\
\text { (Possible udder } \\
\text { health problems) }\end{array}$ & 7 & $2 / 7(28.6 \%)(C)$ & $\begin{array}{l}\text { Staphylococcus warneri (1) } \\
\text { Corynebacterium spp. (1) }\end{array}$ \\
\hline $\begin{array}{l}>1,500,000 \\
\text { (Indicates udder } \\
\text { infection) }\end{array}$ & 20 & $8 / 20(40 \%)(D)$ & $\begin{array}{l}\text { Staphylococcus simulans (5) } \\
\text { Staphylococcus haemolyticus (1) } \\
\text { Staphylococcus saprophyticus \& } \\
\text { Micrococcus spp. (1) } \\
\text { Staphylococcus spp. \& Micrococcus spp. (1) }\end{array}$ \\
\hline Total & 74 & 22 & 24 \\
\hline
\end{tabular}

Ross Peterson, Harry Hariharan, Vanessa Matthew, Graeme Stratton, Cecilia Hegamin-Younger and Ravindra Sharma (2014), International Journal of Veterinary Medicine: Research \& Reports, DOI: 10.5171/2014.710797 
Antibiotic sensitivity tests were performed using a standard disk diffusion method and the results interpreted as per NCCLS guidelines (Quinn et al., 1994). The disks used were: ampicillin, cephalothin, chloramphenicol, clindamycin, erythromycin, gentamicin, neomycin, penicillin, tetracycline, trimethoprim-sulfa, and vancomycin.

\section{Results}

Of a total of 74 udder half samples subjected to Porta-test, 23 were negative for high SCC, and $4 / 23(17.4 \%)$ were culture-positive (Table 1). Of the 51 porta-test- positive samples, consisting of 3 categories, $35.2 \%$ were positive in culture. The differences in culture positivity in the 4 different categories of SCC, however were not statistically significant $(\mathrm{p}=0.41)$.

The most common bacterial species among the 24 isolates recovered was Staphylococcus simulans $(10 / 24)(42 \%)$. Other isolates identified to species level were: $S$. capitis (1), $S$. caprae (1), $S$. haemolyticus (1), $S$. lugdunensis (1), S. saprophyticus (1), S. sciuri (1), and $S$. warneri (1).

Of 24 bacterial isolates tested against 12 antimicrobial drugs, only 2 isolates showed resistance. These were: one $S$. sciuri isolate resistant to penicillin and erythromycin, and one isolate of $S$. capitis resistant to tetracycline.

\section{Discussion}

There is a place in caprine herd health management for goat side tests, as an increase in SCC is an indication of inflammation. If this is detected early and the factors contributing to the elevated SCC are addressed, it would be reasonable to expect that production would be increased. In comparison to the California Mastitis Test, the Porta-test is much more user friendly test that does not require as much training to perform, and therefore there is less subjectivity in the interpretation of the results. Also, antibiotics do not interfere with the test. This would be a more appropriate test than the conventional California Mastitis Test for "on farm" use. A study by Kretschmer et al. (2008) showed that Portatest can be used as an on-farm tool for determining udder health status in sheep as either "healthy" or within the "chronic/clinical mastitis" range. Although it is a convenient and novel tool, Porta-test was not able to differentiate between udder sides between "healthy" and "infection/subclinical mastitis" ranges in sheep. Our results show that it cannot be relied upon as the sole test of caprine udder health in the context of subclinical bacterial mastitis. According to Smith and Sherman (2009), tests other than culture, including SCC determination are unsatisfactory in goats. In this regard, it may be noted that in a study using repeated testing of sheep milk samples during a 10 week period, Hariharan et al., (2004) found no association between SCC and culture positivity. Studies on dairy goats in Switzerland (Schaeren and Maurer, 2006), and the United States (Min et al., 2007) also showed that tests for SCC are of limited value for diagnosis of intramammary infection in goats. These observations, however, contradict the findings of a recent study, which concluded that SCC measurements can be used for the prediction of udder infection in dairy goats (Persson and Olofsson, 2011). Of note, factors other than bacterial infection, such as caprine arthritis and myeloencephlitis virus infection and consumption of avocado (Persea Americana) leaves can cause inflammation of the caprine mammary gland, and increase in SCC (Lerondelle et al., 1992, Smith and Sherman, 2009). There are several non-infectious variation factors of SCC, and these include dietary and medical stresses, and physiological factors such as the stage of lactation, and estrus in goats (Bergonier et al., 2003, Luengo et al., 2004). The inflammatory and immune processes of the caprine udder are not fully understood, and need further research. 
The most frequently isolated bacterial species in this study was Staphylococcus simulans, which is one of the coagulasenegative staphylococci that can be involved in subclinical mastitis in goats (Bergonier et al., 2003, Berry, 2006). Coagulase-negative staphylococci have been found to be the most common organisms isolated from subclinical caprine mastitis in different parts of the world (Contreras et al., 1995, Moroni et al., 2005, Hall and Rycroft, 2007)

Antimicrobial drug resistance among the isolates in this study was minimal or negligible. In contrast, a study of isolates from goats with subclinical mastitis in Italy (Virdis et al., 2010) showed presence of multi-drug resistant Staphylococcus aureus as well as coagulase negative staphylococci. A study in Switzerland showed that in general, compared to $S$. aureus, coagulase-negative staphylococci from goats and sheep have less resistance to penicillin and ampicillin (Kunz et al., 2011).

In summary, the results of Port-test and culture show that the diagnosis of subclinical bacterial mastitis in the caprine cannot be extrapolated with the sole use of Porta- test. However, a high SCC along with culture positivity may indicate intramammary infection. The bacterial isolates and their respective sensitivities in this study were consistent with the findings in other regions of the world.

\section{References}

Bergonier, D., de Crémaux, R., Rupp, R., Lagriffoul, G. \& Berthelot, X. (2003). "Mastitis in Small Dairy Ruminants," Veterinary Research 34: 689-716.

Berry, E. (2006). "Update on Caprine Mastitis," Goat Veterinary Society Journal. 22: 40-42.

Contreras, A., Corrales, J. C., Sierra, D. \& Marco J. (1995). "Prevalence and Aetiology of Non-Clinical Intramammary Infection in
Murciano-Granadina Goats," Small Ruminant Research 17: 71-78.

Hall, S. M. \& Rycroft, A. N. (2007). "Causative Organisms and Somatic Cell Counts in Subclinical Intramammary Infections in Milking Goats in the UK," Veterinary Record 160: 19-22.

Hariharan, H., Donachie, W., Macaldowie, C. \& Keefe, G. (2004). "Bacteriology and Somatic Cell Counts in Milk Samples from Ewes on a Scottish Farm," Canadian Journal of Veterinary Research 68:188-192.

Kretschmer, E. R., Holcombe, D. W., Fernandez, G. C. J. \& Redelman, D. (2008). 'Efficacy of the PoraSCC $®$ Milk Test to Estimate Somatic Cell Count (SCC) and Effect of Sampling Day on Constituents in Sheep Milk,' Proceedings, Western Section, American Society of Animal Science 59: 281-284.

Kunz, F., Corti, S., Giezendanner, N., Stephan, R., Wittenbrink, M. \& Zweifel, C. (2011). "Antimicrobial Resistance of Staphylococcus Aureus and Coagulase Negative Staphylococci Isolated from Mastitis Milk Samples from Sheep and Goats," Schweizer Archiv Fur Tierheilkunde 153: 63-69.

Lerondelle, C., Richard, Y., \& Issartial, J. (1992). "Factors Affecting Somatic Cell Counts in Goat Milk," Small Ruminant Research 8:129-139.

Leslie, K., Baratt, K., Petersson, C. \& Bashiri, A. (2006). "An Evaluation of the PortaSCC $\AA$ Test as a Measure of Udder Health Status of Dairy Cows (An Excerpt from a Technical Report),"

http://www.portacheck.com/guelph.php (Accessed 10/15/2013).

Luengo, C., Sánchez, A., Corrales, J. C., Fernández, C. \& Contreras, A. (2004). "Influence of Intramammary Infection and Non-Infection Factors on Somatic Cell Counts in Dairy Goats," Journal of Dairy Research 71: 169-174. 
Min, B. R., Tomita, G. \& Hart, S. P. (2007). "Effect of Subclinical Intramammary Infection on Somatic Cell Counts and Chemical Composition of Goat's Milk," Journal of Dairy Research 74:204-210.

Moroni, P., Pisoni, G., Antonini, M., Ruffo, G., Carli, S., Varisco, G. \& Boettcher, P. (2005). "Subclinical Mastitis and Antimicrobial Susceptibility of Staphylococcus Caprae and Staphylococcus Epidermidis Isolated from Two Italian Goat Herds," Journal of Dairy Science 88: 1694-1704.

Oliszewski, R., Nunez de Kairuz, M., Gonzalez, S. \& Oliver, G. (2004). "Beta-glucuronidase method to Determine Mastitis Levels in Goat Milk," In: Methods in Molecular Biology, vol. 268: Public Health Microbiology: Methods and Protocols. Spencer, J. F. T. \& Ragout de Spencer, A. L. (Eds.) Humana Press Inc., Totowa, N.J., USA. 475-479.

Persson, Y. \& Olofsson, I. (2011). "Direct and Indirect Measurement of Somatic Cell Count as Indicator of Intramammary Infection in Dairy Goats," Acta Veterinaria Scandinavica 53:15.

Petersson, K. H., Connor, L. A., PeterssonWolfe, C. S. \& Rego, K. A. (2011). "Short Communication: Evaluation of Confirmatory Stains Used for Direct Microscopic Somatic Cell Counting of Sheep Milk," Journal of Dairy Science 94: 1908-1912.
Philpot, W. N. (1984). Mastitis Management, 2nd edition. Babson Bros. Co., Oak Brook, Illinois, USA. 5-6.

Quinn, P. J., Carter, M. E., Markey, B. K. \& Carter, G. R. (1994). 'Clinical Veterinary Microbiology,' Wolfe/Mosby Publishing, London, UK. 49-335.

Ruegg, P. L. \& Rienemann, D. J. (2002). "Milk Quality and Mastitis Tests," University of Wisconson, Madison. http://milkquality.wisc.edu/wpcontent/uploads/2011/...

Schaeren, W. \& Maurer, J. (2006). "Prevalence of Subclinical Udder Infection and Individual Somatic Cell Counts in Three Dairy Goat Herds during a Full Lactation," Schweizer Archiv Fur Tierheilkunde. 148:641-648.

Smith, M. C. \& Sherman, D. M. (2009). Goat Medicine, 2nd edition, Wiley-Blackwell, Ames, Iowa. 647-689.

Virdis, S., Scarano, C., Cossu, F., Spanu, V., Spanu, C. \& De Santis, E. P. L. (2010). "Antibiotic Resistance in Staphylococcus Aureus and Coagulase Negative Staphylococci Isolated from Goats with Subclinical Mastitis," Veterinary Medicine International , 6 pages. 